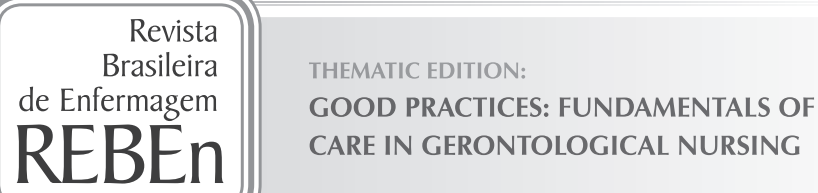

\title{
Stress and optimism of elderlies who are caregivers for elderlies and live with children
}

\author{
Estresse e otimismo de idosos cuidadores de idosos que residem com crianças \\ Estrés y optimismo de ancianos cuidadores de otros ancianos que residen con niños
}

\section{Nathalia Alves de Oliveira', Érica Nestor Souza', Bruna Moretti Luchesi', Keika Inouye", Sofia Cristina Iost Pavarini,"II}

\begin{abstract}
' Universidade Federal de São Carlos, Postgraduate Program in Nursing. São Carlos, São Paulo, Brazil.
"Universidade Federal de São Carlos, Postgraduate Program in Gerontology. São Carlos, São Paulo, Brazil
\end{abstract}

How to cite this article:

Oliveira NA, Souza EN, Luchesi BM, Inouye K, Pavarini SCI. Stress and optimism of elderlies who are caregivers for elderlies and live with children. Rev Bras Enferm [Internet]. 2017;70(4):697-703. [Thematic Edition "Good Practices: Fundamentals of care in Gerontological Nursing"] DOI: http://dx.doi.org/10.1590/0034-7167-2017-0088

\section{Submittssion: 02-15-2017 Approval: 03-18-2017}

\begin{abstract}
Objective: to evaluate the relation between stress and optimism of elderlies who are informal caregivers for elderlies and live with children. Method: cross-sectional study on 50 elderlies who provide care to elderlies, live with children, and are registered in the primary health care. The interviews occurred in the participant's residence and we evaluated characteristics of the care-dependent elderly and of the children, sociodemographic characteristics, stress through the Perceived Stress Scale and optimism through the Pinto and Pais-Ribeiro Spirituality Scale, in the elderly caregiver. For statistical analysis we used the Spearman correlation test. Results: the mean level of stress was 23.9 points and of optimism was 3.3 points. Correlation analysis showed that the higher the level of optimism the significantly lower the level of perceived stress of elderlies who provided care to elderlies and lived with children. Conclusion: inversely proportional correlation was identified between stress and optimism. Descriptors: Elderly; Child; Caregivers; Family Relationships; Relationship Between Generations.
\end{abstract}

\section{RESUMO}

Objetivo: avaliar a relação entre estresse e otimismo de idosos cuidadores informais de idosos e que residem com crianças. Método: estudo transversal com 50 idosos cuidadores de idosos que residem com crianças e são cadastrados na atenção básica. As entrevistas ocorreram no domicílio do participante e foram avaliadas características do idoso dependente de cuidados e das crianças, características sociodemográficas, estresse por meio da Escala de Estresse Percebido e o otimismo por meio da Escala de Espiritualidade de Pinto e Pais-Ribeiro, no idoso cuidador. Para análise estatística foi utilizado o teste correlação de Spearman. Resultados: o nível médio de estresse foi de 23,9 pontos e de otimismo foi de 3,3 pontos. A análise de correlação mostrou que quanto maior o nível de otimismo significativamente menor foi o nível de estresse percebido dos idosos cuidadores de idosos que residiam com crianças. Conclusão: foi identificada correlação inversamente proporcional entre estresse e otimismo.

Descritores: Idoso; Criança; Cuidadores; Relações Familiares; Relação Entre Gerações.

\section{RESUMEN}

Objetivo: evaluar la relación entre estrés y optimismo en ancianos cuidadores informales de otros ancianos que residen con niños. Método: estudio transversal con 50 ancianos cuidadores de ancianos que residen con niños, registrados en atención básica. Entrevistas realizadas en domicilio del participante, evaluándose características del anciano dependiente de cuidados y de los niños, características sociodemográficas, estrés mediante Escala de Estrés Percibido y optimismo mediante Escala de Espiritualidad de Pinto y Pais-Ribeiro, en el anciano cuidador. Para análisis estadístico, se utilizó test de correlación de Spearman. Resultados: el nivel medio de estrés fue de 23,9 puntos, el de optimismo fue de 3,3 puntos. El análisis de correlación expresó que cuanto mayor fue el nivel de optimismo, significativamente menor fue el nivel de 
estrés percibido en los ancianos cuidadores de otros ancianos que residen con niños. Conclusión: se identificó correlación inversamente proporcional entre estrés y optimismo.

Descriptores: Anciano; Niño; Cuidadores; Relaciones Familiares; Relaciones Intergeneracionales.

\section{INTRODUCTION}

The formation of new family arrangements has increased as a result of changes in the social structures and of the growing number of elderlies in the population. In these new arrangements, it has been observed an increasing prevalence of elderlies who carry out the work of informal caregiver (unpaid) for other more dependent elderlies and at the same time reside with and aid in the care of grandchildren ${ }^{(1-2)}$.

This context that has the elderly as protagonist in the intergenerational care may lead this elderly to perform a wide amount of tasks that require different skills to deal with caring for child and elderly, since both are in different stages of life and require different care and stimuli.

Researches that analyze the physical and psychological health of caregivers of elderly in general, elderly caregivers of elderly carerecipients ${ }^{(2-3)}$, and grandparents who care for grandchildren ${ }^{(4)}$ note that the stress level is a variable with potential negative effect on health, quality of care, and quality of intergenerational relationships, a variable that is present in different contexts of care ${ }^{(2-4)}$.

Stress can be understood as a response of the body that is exposed to excessive demands, so its reaction will raise the stress level, culminating in psychological and biological risks to health ${ }^{(5-6)}$.

An American study, which evaluated for eight years the effects of stress in 375 elderly caregivers and 694 elderly noncaregivers, found higher level of stress and risk of mortality in elderly who were caregivers and concluded that the effects of stress increase the chances of health decline in elderly caregivers $^{(7)}$. Another cross-sectional study carried out with 90 caregivers of seniors with dementia in Colombia assessed the relation between family dynamics and mental health, indicating that better family dynamics is associated with lower depression and stress of the caregiver ${ }^{(8)}$.

In the literature, intergenerational studies have indicated that coresidence with elderlies and children is beneficial, since it approaches generations that are not closely related. On the other hand, research notes the high intensity of the care that elderlies provide to children, which may lead the elderlies to experience higher levels of overload and stress ${ }^{(9-10)}$.

Although studies show that the level of stress caused by the demands of the care may interfere negatively with the health, the care, and the intergenerational relationships, there is few research that investigates mechanisms of the caregiver's personality that can help professionals to develop interventions that reduce the negative effects of care. Among these mechanisms there is the level of optimism.
Optimism is described as a characteristic of personality capable of encouraging the person into seeking strategies of adaptation to the context of care ${ }^{(11)}$. Moreover, optimism is linked to positive aspects that improve the physical and psychological health and can aid in managing stressful situations ${ }^{(12)}$.

There is a growing trend towards the elderly taking on the responsibilities of care in the family, and it is important that studies investigate the caregivers' characteristics that can enable interventions and programs aimed to mitigate the negative effects of stress on their health. Therefore, this study aimed to evaluate the relation between stress and optimism in elderlies who carry out the work of informal caregivers for other elderlies and who reside with children.

\section{METHOD}

\section{Ethical aspects}

This research follows the guidelines of Resolution $466 / 2012$, of the National Council of Health. This study was approved by the Research Ethics Committee of the University. All participants were informed about the purpose of the research and the informed consent form was presented and discussed with each participant and after due clarification we requested them to sign and handed a copy of the document to each participant.

\section{Study design, location, and period}

This is a cross-sectional and quantitative research conducted in the period from April to November 2014 with elderlies who provided care for elderlies, lived with children, and were registered in Family Health Units (FHU) of the city of São Carlos-SP.

\section{Population and sample; inclusion criteria and exclusion criteria}

The inclusion criteria established in this study were: being aged 60 years or over; being registered and reside in one of the 18 catchment areas of the FHUs; being an informal caregiver (unpaid) in residence of elderly dependent for one or more Basic Activity of Daily Living (BADL), evaluated by Katz index ${ }^{(13)}$ and/or Instrumental Activity of Daily Living (IADL) evaluated by Lawton and Brody Scale ${ }^{(14)}$; and residing with at least one child aged 12 years or less. The exclusion criterion was: all the elderly of the residence score as independent in the evaluation of BADLs and IADLs. In order to identify the population, we requested from the FHUs in the municipality a list containing name, age, and address of households with two or more elderlies. A list with a total of 594 residences was provided. Figure 1 presents the sample selection flowchart based on the inclusion and exclusion criteria. 


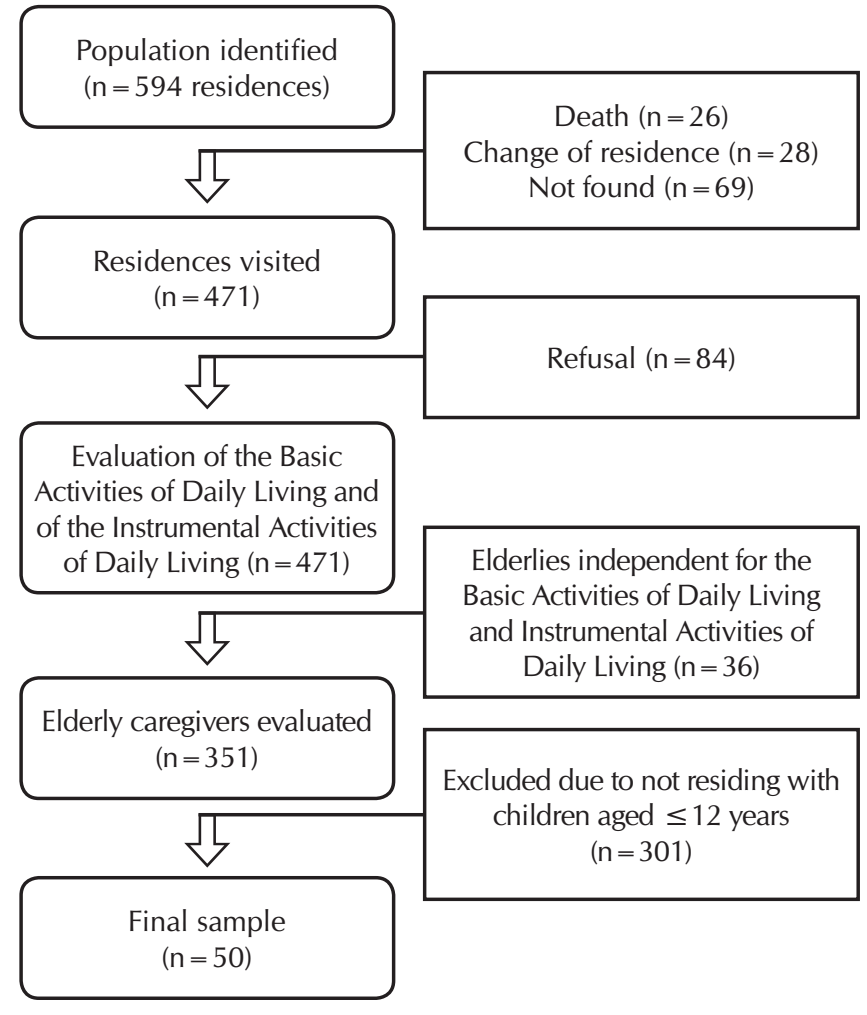

Figure 1 - Sample selection flowchart, São Carlos, São Paulo, Brazil, 2014

\section{Study protocol}

A team composed of gerontologists, nurses, and undergraduate students of Gerontology was trained by the lead researcher to manage and apply the instruments. The elderly in the study were interviewed by two evaluators. The interviews were conducted in the participant's residence, in single and individual session with approximate duration of 1 hour and 30 minutes.

Initially, all elderlies of the residence participated in a pre-assessment to determine their level of independence. Based on the inclusion and exclusion criteria, the evaluators defined who were the elderly providing care (more independent) and the elderly receiving care (more dependent). In residences with more than two elderlies, all participated in the pre-assessment; however, in this study we included only the elderly with the highest level of independence and the elderly with the highest level of dependence in the evaluation. After the classification of the elderly caregiver and of the elderly carerecipient, they were interviewed individually by independent researchers. Thus, the assessment protocol with the variables of interest was divided into the order presented below.

Pre-evaluation (applied to all elderlies of the residence) composed of Katz Index - to determine the level of dependence for the BADLs (independent or dependent for 1-6 activities) ${ }^{(13)}-$ and Lawton Scale - with seven questions that assess the IADLs. The total score can range from 7 to 21 points. Score of 7 points indicate total dependence, $8-20$ points indicate partial dependence, and 21 points indicate independence ${ }^{(14-15)}$.

Evaluation of the elderly carerecipient: sex (female or male) and age (60-69, 70-79, 80 years or over).

Evaluation of the elderly caregiver:
- Characteristics of the sociodemographic, health, and care profile: sex, age (60-69, 70-79, 80 years or over), marital status (married, single, divorced, widowed), educational level (in years), individual income (BRL), selfreported household income (BRL), health status (selfreported diseases, regular use of medications, subjective evaluation of health), degree of kinship with the elderly carerecipient (spouse, parent, other), time as caregiver (in years) and the mean number of hours per day providing care to the dependent elderly, if receives emotional/affective or financial aid to provide care (yes, no).

- Children's characteristics: sex, age (in years), degree of kinship with elderly caregiver (grandfather/grandmother, great-grandfather/great-grandmother, father/mother, other), time residing with the elderly (in years), if receives daily care from the elderly caregiver and hours per day receiving care from the elderly caregiver.

- Perceived stress: we used the Perceived Stress Scale (PSS) translated and validated for use in the elderly in Brazil( ${ }^{(16)}$ to assess how the elderly perceive everyday situations as stressful. The scale has 14 questions, is easy to apply, and the score can range from 0 to 56 points. The higher the score, the higher is the level of stress. This variable was used as continuous.

- Evaluation of optimism: we used the "Hope and Optimism" domain of the Pinto and Pais-Ribeiro Spirituality Scale (PPRSS), translated and adapted to the Brazilian context ${ }^{(17)}$. The scale is easy to apply and the score for this dimension corresponds to the mean of questions 3,4 , and 5 that are part of the scale. It can range from 4 to 12 points and the higher the score the higher the level of agreement with the dimension evaluated. This variable was used as continuous.

\section{Analysis of results and statistics}

The data were entered and validated with double and blind entry in Epitata 3.1 and exported to Statistical Package for the Social Sciences (SPSS for Windows), version 20.0. For descriptive analysis of the data, we calculated measures for central position (mean, median, minimum, and maximum) and dispersion (standard deviation). Kolmogorov-Smirnov test was used to analyze data normality and given the absence of data normality $(p=0.00)$ we used the Spearman correlation test. Magnitude of correlations was classified as weak $(<0.3)$, moderate $(0.3$ to 0.59$)$, strong $(0.6$ to 0.9$)$, and perfect $(1.0)^{(18)}$. For all statistical tests, the level adopted was $5 \%(p \leq 0.05)$.

\section{RESULTS}

Table 1 presents sociodemographic and economic characteristics of the elderly caregivers.

As to the health conditions of the elderly caregivers, the most reported were hypertension $(76.0 \% ; n=38)$ and back problems $(58.0 \% ; n=29)$. In relation to the use of medications, $98.0 \%(n=49)$ makes regular use of medication. As to the subjective evaluation of health, $46 \%(n=23)$ of the elderly caregivers consider the health as regular and the care taken as $\operatorname{good} /$ very good $(36 \% ; n=35)$.

In the evaluation of the context of care provided to the elderly, it was found that the most prevalent degree of kinship 
between the elderly caregiver and the elderly carerecipient was spouse $(88.0 \% ; n=44)$, followed by father/mother; father/ mother-in-law, and others $(4.0 \% ; n=2$ each). Most elderly caregivers $(52.0 \% ; n=26)$ report receiving emotional/affective aid to face the demands of care and being caregivers on average for $9.5( \pm 5.9)$ years, providing care on average for 7.0 $( \pm 5.2)$ hours per day. Table 2 presents the social and dependence characteristics of the elderly carerecipients.

Table 1 - Distribution of the frequency and median of the demographic and socioeconomic variables of the elderly caregivers $(n=50)$ who live with children and are registered in the Family Health Units of São Carlos, São Paulo, Brazil, 2014

\begin{tabular}{|c|c|c|c|}
\hline Variable & $\mathbf{n}$ & $\%$ & Median \\
\hline \multicolumn{4}{|l|}{ Sex } \\
\hline Female & 39 & 78.0 & \\
\hline Male & 11 & 22.0 & \\
\hline \multicolumn{4}{|l|}{ Age } \\
\hline $60-69$ years & 28 & 56.0 & \\
\hline $70-79$ years & 19 & 38.0 & \\
\hline 80 years or over & 3 & 6.0 & \\
\hline \multicolumn{4}{|l|}{ Marital status } \\
\hline Married & 44 & 88.0 & \\
\hline Single & 2 & 4.0 & \\
\hline Divorced & 2 & 4.0 & \\
\hline Widower & 2 & 4.0 & \\
\hline Educational level & & & 3.3 \\
\hline *Household income (BRL) & & & $2,172.0$ \\
\hline *Caregiver's income (BRL) & & & 724.0 \\
\hline
\end{tabular}

Table 2 - Distribution of the frequencies of the demographic variables and dependency variables for the basic and instrumental activities of daily living of the elderly carerecipients $(n=50)$, São Carlos, São Paulo, Brazil, 2014

\begin{tabular}{|c|c|c|}
\hline Variable & $\mathbf{n}$ & $\%$ \\
\hline \multicolumn{3}{|l|}{ Sex } \\
\hline Male & 40 & 80.0 \\
\hline Female & 10 & 20.0 \\
\hline \multicolumn{3}{|l|}{ Age } \\
\hline $60-69$ years & 27 & 54.0 \\
\hline $70-79$ years & 19 & 38.0 \\
\hline 80 years or over & 4 & 8.0 \\
\hline \multicolumn{3}{|c|}{ *Dependency for at least one BADL } \\
\hline Yes & 7 & 14.0 \\
\hline No & 43 & 86.0 \\
\hline \multicolumn{3}{|c|}{ **Dependency for the IADLs } \\
\hline Partial & 46 & 92.0 \\
\hline Total & 4 & 8.0 \\
\hline
\end{tabular}

Note: *BADL $=$ Basic Activity of Daily Living; $* * I A D L=$ Instrumental Activity of Daily Living.
When evaluating characteristics of the children who lived with the elderly caregivers, it was found that in the 50 households interviewed there were 68 children, $54.4 \%(n=37)$ male and $45.6 \%(n=31)$ female, with mean age of 5.9 years $( \pm 3.5)$.

The predominant degree of kinship between the child and the elderly caregiver was grandfather/grandmother (85.2\%; $\mathrm{n}=58)$, followed by great-grandfather/great-grandmother $(5.9 \% ; n=4)$, other $(5.9 \% ; n=4)$, and father/mother $(3.0 \%$; $\mathrm{n}=2)$. Time of coresidence between the child and the elderly caregiver was 5.4 years $( \pm 5.0)$ on average. All children $(100 \%$; $\mathrm{n}=68$ ) received care provided by the elderly caregiver and the mean number of hours of care per day was 5.9 hours $( \pm 5.0)$.

As to the evaluation of optimism and perceived stress for elderly caregivers, Table 3 presents the medians, means, standard deviation, and variation of the evaluations.

Analysis of correlation between the optimism domain of the PP-RSS and the PSS showed the existence of negative correlation and moderate magnitude $(r=-0.484)$, statistically significant $(p=0.00)$, showing that the higher the level of optimism the lower the level of perceived stress among the elderly caregivers.

Table 3 - Descriptive statistics of the scores obtained by the elderly caregivers who live with children $(n=50)$ on the Spirituality Scales for evaluation of optimism and perceived Stress, São Carlos, São Paulo, Brazil, 2014

\begin{tabular}{lcccc}
\hline Variable & Median & Mean & $\begin{array}{c}\text { Standard } \\
\text { deviation }\end{array}$ & $\begin{array}{c}\text { Variation } \\
\text { found }\end{array}$ \\
\hline Optimism & 3.7 & 3.3 & 0.7 & $1-4$ \\
Perceived stress & 22.0 & 23.9 & 12.7 & $5-56$ \\
\hline
\end{tabular}

\section{DISCUSSION}

Results of this study show that the mean score for the optimism domain of PP-RSS was $3.3 \pm 0.7$ points and for PSS $23.9 \pm 12.7$ points. The higher the level of optimism, the significantly lower the level of perceived stress for elderly caregivers who live with children.

Using the PP-RSS in 127 adults and seniors who were chronic kidney patients, researchers found higher mean for optimism domain than that of this study, with score of 3.6 points ${ }^{(19)}$. In Portugal, a research with 47 elderlies of a Long-stay Institution found a score of 3.1 points ${ }^{(20)}$ for the domain.

When analyzing studies that applied the PSS in elderly in different contexts, the mean found was lower than that of a research conducted in the United States, 26.9 points ${ }^{(5)}$, and higher than that of two Brazilian studies that obtained mean of 18.5 points $^{(6)}$ and 14.0 points $^{(21)}$.

In Brazil, researchers used the PSS to assess the factors associated with perceived stress in 341 elderlies who provided care to elderlies in different contexts of dependence that resided in the community. The mean score found in the evaluation of stress was 18.5 points. Among the associated factors, it was found that the greater the number of individuals living in the house the greater the stress level in the elderly caregiver ${ }^{(22)}$. 
The relation between stress and optimism was one of the objectives of a study with 172 adults, which indicated, among the results, that the higher the optimism the lower was the stress caused by the daily work ${ }^{(23)}$. In Seoul, a study with 252 elderly ladies evaluated if optimism would be related with the subjective wellbeing and the meaning of life, observing that the more optimist elderly tend to give greater meaning to life, which contributes to increase the subjective wellbeing ${ }^{(24)}$.

In context of care provided to the elderly, the variable optimism has shown positive effect on the negative aspects produced by the overload of daily care, among which is the stress $^{(25)}$. In the studies referenced, it is observed that both optimism and stress present scores that vary depending on the context and on the population studied, and both variables may be influenced by environmental and cultural elements.

In the literature, studies have shown that optimism is an effective measure for reduction of stress in different scenarios of evaluation ${ }^{(23,25)}$. In this study it was also found that optimism reduces stress in elderlies that care for elderlies and live with children. Such information can be used to stimulate the development of programs and actions with focus, increase the level of optimism and encourage the positive aspects of intergenerational coexistence and care.

Intergenerational care from grandparents exercising the role of caregivers of grandchildren shows that there are positive and negative elements in the daily care. In Australia, researchers investigated the psychological health of 100 grandparents who were primary caregivers of grandchildren with behavioral and social disorders. The result of the study showed that grandparents who cared for grandchildren with emotional disorders and hyperactivity had higher levels of stress, anxiety, and depression and were more likely to report lower levels of satisfaction with life when compared with grandparents that did not exercise the role of primary caregivers of grandchildren ${ }^{(26)}$.

In a European study that evaluated the cognitive health of grandparents who cared for grandchildren, it was observed that the daily care for grandchildren showed no positive effects for the cognitive health of the elderly ${ }^{(27)}$. In China, in examining the effects of the intensity of care for grandchildren on grandparents' life, researchers found that low-intensity care has protective effect for the grandparents' health, while grandparents providing highintensity daily care experience an accelerated decline in health ${ }^{(9)}$.

From another perspective, many studies have found evidence that providing care to grandchildren has positive effect on the physical, emotional, and cognitive health of the elderly. In a research that evaluated over four years the role of being a caregiver for the child or adolescent grandchild on the health of grandparents, it was found that grandparents that were caregivers presented better cognitive health and better performance in basic and instrumental activities of daily living ${ }^{(28)}$.

Data from a longitudinal study conducted in Latin America with 2,000 elderlies that analyzed the factors associated with the provision of help from grandparents to grandchildren showed that the care provided to grandchildren for over 4 hours a week decreased the grandparents' risk of developing depression and, on the other hand, increased the levels of satisfaction with life ${ }^{(29)}$. In another study, researchers found that grandparents who cared for multiple generations over time were likely to report better selfassessment of health and lower limitation of mobility ${ }^{(4)}$.

Based on the studies described above, it can be observed a spread between positive and negative elements that are involved in the care provided by the elderly to the children. However, it is important that professionals pay attention to the positive aspects, as these can be important tools to indicate ways to minimize the negative impact of care and to foster intergenerational exchanges, through policies and programs focused on bringing distant generations closer.

In addition, the positive aspects can have a major influence on the quality of the relationships that are being formed between the children and the elderly, since these children may represent influential sources of social support for the elderly. Accordingly, a Brazilian study compared the relations between social support and cognitive changes in the elderly, taking into consideration the presence or absence of children in the household, and observed better level of social support in households with the presence of children ${ }^{(30)}$.

\section{Limitations of the study}

Some limitations may be mentioned in this research. The study's cross-sectional design does not allow us to determine the action of time on the variables and the absence of a group of elderly caregivers who do not live with children does not allow us to compare these variables in contexts with and without children. In this study, we evaluated the relation between stress and optimism in elderlies who provide care to elderlies and to children. Optimism proved to be an important aspect for reducing stress in the caregiver, but other variables - such as the intensity of care provided to the children and to the elderly, the social support, and the quality of the relationships - can influence the variables of optimism and stress. Such factors can be analyzed in future researches.

\section{Contributions to the fields of nursing, public health, or public policy}

Results found in this study can contribute to the development of public policies geared towards the care provided to the elderlies' family caregivers, to improvements in the promotion of physical and psychological health of these individuals, to the improvement and enhancement of intergenerational programs aimed at bringing the children and the elderly closer, in addition to stimulate the good quality of the relationships and exchanges of intergenerational care.

\section{CONCLUSION}

In this study, it was found moderate and inversely proportional correlation between the variables stress and optimism, and the higher the level of optimism the lower the level of stress in a sample of elderlies who are informal caregivers for other elderlies and live with children.

\section{FUNDING}

This research received financial support from the Conselho de Aperfeiçoamento de Nível Superior (Master's degree) and from the São Paulo Research Foundation, process number: 2014/01092-9. 


\section{REFERENCES}

1. Ramos AC. Os Avós na Literatura Infantil: perspectivas gerontológicas e educacionais. Educ Real. 2015;40(1).

2. Luchesi BM, Alexandre TD, de Oliveira NA, Brigola AG, Kusumota L, Pavarini SC, Marques S. Factors associated with attitudes toward the elderly in a sample of elderly caregivers. Intern Psychoger [Internet]. 2016 [cited 2016 Oct 14];1. Available from: http:// dx.doi.org/10.1017/S1041610216001538

3. Souza LR, Hanus JS, Libera D, Bolzan L, Silva VM, Mangilli EM, Tuon L. Sobrecarga no cuidado, estresse e impacto na qualidade de vida de cuidadores domiciliares assistidos na atenção básica. Cad Saúde Colet [Internet]. 2015 [cited 2016 Oct 14];23(2). Available from: http://dx.doi.org/10.1590/1414-462X201500020063

4. Ku LJE, Stearns SC, Van Houtven CH, Lee SYD, Dilworth-Anderson P, Konrad TR. Impact of caring for grandchildren on the health of grandparents in Taiwan. J Gerontol B Psychol Sci Soc Sci [Internet]. 2013 [cited 2016 Oct 14];68(6):1009-21. Available from: http://dx.doi.org/10.1093/geronb/gbt090

5. Mehta AJ, Kubzansky LD, Coull, BA, Kloog, I, Koutrakis, P, Sparrow, D, SpirollI, A, Vokonas, P, Schwartz, J. Associations between air pollution and perceived stress: the Veterans Administration Normative Aging Study. Environ Health [Internet]. 2015 [cited 2016 Oct 14];14(1):1-10. Available from: http://dx.doi.org/10.1186/1476-069X-14-10

6. Conceição JCR, Mazo GZ, Benedetti TRB, Dias RG, Krug RR. Relação das características sociodemográficas com o estresse percebido em idosos praticantes de exercícios físicos. RBCEH [Internet]. 2012 [cited 2016 Oct 14];9(1):89-97. Available from: http://dx.doi.org/10.5335/rbceh.2012.1843

7. Fredman L, Cauley JA, Hochberg M, Ensrud KE, Doros G. Mortality associated with caregiving, general stress, and caregivingrelated stress in elderly women: results of caregiver-study of osteoporotic fractures. JAGS [Internet]. 2010 [cited 2016 Oct 14];58(5):937-43. Available from: http://dx.doi.org/10.5335/rbceh.2012.1843

8. Sutter M, Perrin PB, Chang Y, Hoyos GR, Buraye JA, Arango-Lasprilla JC. Linking family dynamics and the mental health of Colombian dementia caregivers. Am J Alzheimers Dis Other Demen [Internet]. 2014 [cited 2016 Oct 14];29(1):67-75. Available from: http://dx.doi.org/10.1177/1533317513505128

9. Chen F, Liu G. The health implications of grandparents caring for grandchildren in China. J Gerontol B Psychol Sci Soc Sci [Internet]. 2012 [cited 2016 Oct 14];67(1):99-112. Available from: http://dx.doi.org/10.1093/geronb/gbr132

10. Schuler E, Dias C. Avós que criam seus netos-Uma proposta de intervenção psicoeducativa. CIAIQ2014 [internet]. 2015 [cited 2016 Oct 14];2. Available from: http://proceedings.ciaiq.org/index.php/CIAIQ/article/view/509/504

11. Vilhena E, Pais-Ribeiro J, Silva I, Pedro L, Meneses RF, Cardoso H, Mendonça D. Optimism on quality of life in Portuguese chronic patients: moderator/mediator?. Rev. Assoc. Med. Bras [Internet]. 2014 [cited 2016 Oct 14];60(4):373-80. Available from: http:// dx.doi.org/10.1590/1806-9282.60.04.017

12. Boehm JK, Kubzansky LD. The heart's content: the association between positive psychological well-being and cardiovascular health. Psychol Bull [Internet]. 2012 [cited 2016 Oct 14];138(4):655. Available from: http://dx.doi.org/10.1037/a0027448

13. Katz S, Ford AB, Moskowitz RW, Jackson BA, Jaffe MW. Studies of illness in the aged: the index of ADL: a standardized measure of biological and psychosocial function. Jama [Internet]. 1963 [cited 2016 Oct 14];185(12):914-9. Available from: http://dx.doi. org/10.1001/jama.1963.03060120024016

14. Lawton MP, Brody EM. Assessment of older people: self-maintaining and instrumental activities of daily living. Gerontol. 1969;9:179-86.

15. Dos Santos RL, Virtuoso Júnior JS. Confiabilidade da versão brasileira da escala de atividades instrumentais da vida diária. RBPS [Internet]. 2008 [cited 2016 Oct 14]; 21(4):290-6. Available from: http://hp.unifor.br/pdfs_notitia/2974.pdf.

16. LuftCB, Sanches SO,Mazo GZ, AndradeA. Versão brasileira da Escala de Estresse Percebido: traduçãoe validação para idosos. Rev Saúde Pública [Internet]. 2007 [cited 2016 Oct 14];41(4):606-15. Available from: http://dx.doi.org/10.1590/S0034-89102007000400015

17. Pinto C, Pais-Ribeiro JL. Construção de uma escala de avaliação da espiritualidade em contextos de saúde. Arq Med [Internet]. 2007 [cited 2016 Oct 14];21(2):47-53. Available from: http://www.scielo.mec.pt/pdf/am/v21n2/v21n2a02.pdf

18. Levin J, Fox JA. Estatística para ciências humanas. São Paulo: Prentice-Hall; 2004.

19. Ottaviani AC, Souza ÉN, de Camargo Drago N, de Mendiondo MSZ, Pavarini SCI, de Souza Orlandi F. Esperança e espiritualidade de pacientes renais crônicos em hemodiálise: estudo correlacional. Rev. Latino-Am Enfermagem [Internet]. 2010 [cited 2016 Oct 14];22(2):248-54. Available from: http://dx.doi.org/10.1590/0104-1169.3323.2409

20. Soares ADSF, Amorim MISPL. Qualidade de vida e espiritualidade em pessoas idosas institucionalizadas. Rev. Port. de Enf. de Saúde Men [Internet]. 2015 [cited 2016 Dec 27];(2. Esp);45-51. Available from: http://www.scielo.mec.pt/pdf/rpesm/nspe2/ nspe2a08.pdf

21. Santos EB, Rodrigues RAP, Marques S, Pontes-Neto OM. Perceived stress in elderly stroke survivors after hospital discharge to home. Rev Esc Enferm USP [Internet]. 2015 [cited 2016 Oct 14];49(5):797-803. Available from: http://dx.doi.org/10.1590/ S0080-623420150000500013 
22. Luchesi BM, Souza ÉN, Gratão ACM, de Oliveira Gomes GA, Inouye K, da Silva Alexandre T, Pavarini, SCl. The evaluation of perceived stress and associated factors in elderly caregivers. Arch Gerontol Ger [Internet]. 2016 [cited 2016 Oct 14];67:7-13. Available from: http://dx.doi.org/10.1016/j.archger.2016.06.017

23. Avey JB, Wernsing TS, Mhatre KH. A longitudinal analysis of positive psychological constructs and emotions on stress, anxiety, and well-being. J Leadership Org Studies [Internet]. 2011 [cited 2016 Oct 14]. Available from: http://dx.doi. org/10.1177/1548051810397368

24. Ju H, Shin JW, Kim CW, Hyun MH, Park JW. Mediational effect of meaning in life on the relationship between optimism and well-being in community elderly. Arch Gerontol Ger [Internet]. 2013 [cited 2016 Oct 14];56(2):309-13. Available from: http:// dx.doi.org/10.1016/j.archger.2012.08.008

25. Mackay C, Pakenham KI. Identification of stress and coping risk and protective factors associated with changes in adjustment to caring for an adult with mental illness. J Clin Psychol [Internet]. 2011 [cited 2016 Oct 14];67(10):1064-79. Available from: http:// dx.doi.org/10.1002/jclp.20829

26. Doley R, Bell R, Watt B, Simpson H. Grandparents raising grandchildren: investigating factors associated with distress among custodial grandparent. J Fam Studies [Internet]. 2015 [cited 2016 Oct 14];21(2):101-19. Available from: http://dx.doi.org/10.108 $0 / 13229400.2015 .1015215$

27. Arpino B, Bordone V. Does grandparenting pay off? the effect of child care on grandparents' cognitive functioning. J Marriage Fam [Internet]. 2014 [cited 2016 Oct 14];76(2):337-51. Available from: http://dx.doi.org/10.1111/jomf.12096

28. Zhou J, Mao W, Lee Y, Chi I. The Impact of Caring for Grandchildren on Grandparents' Physical Health Outcomes The Role of Intergenerational Support. Res Aging [Internet]. 2016 [cited 2016 Oct 14];0164027515623332. Available from: http://dx.doi. org/10.1177/0164027515623332

29. Grundy EM, Albala C, Allen E, Dangour AD, Elbourne D, Uauy R. Grandparenting and psychosocial health among older Chileans: a longitudinal analysis. Aging Mental Health [Internet]. 2012 [cited 2016 Oct 14];16(8):1047-1057. Available from: http://dx.doi. org/10.1080/13607863.2012.692766

30. Luchesi BM, de Brito TRP, Costa RS, Pavarini SC.I. Suporte social e contato intergeracional: estudando idosos com alterações cognitivas. R. Eletron Enferm [Internet]. 2016 [cited 2016 Oct 14];17(3). Available from: http://dx.doi.org/10.5216/ree.v17i3.25597 